\title{
Three operational models for ambidexterity in large corporations
}

\author{
Sverker Alänge ${ }^{1 *}$ (D) and Annika Steiber ${ }^{2}$
}

\author{
* Correspondence: \\ sverker.alange@chalmers.se \\ 'Department of Technology \\ Management and Economics - STS, \\ Chalmers University of Technology, \\ SE-412 96 Gothenburg, Sweden \\ Full list of author information is \\ available at the end of the article
}

\begin{abstract}
This paper examines new approaches that large firms are using to become more ambidextrous - more able to "explore" and innovate for the future while they "exploit" current lines of business. It presents and compares three different models for boosting innovation by partnering with external actors: GE Appliances' FirstBuild unit for new-product development, the Open Innovation function at Electrolux, and Lantmännen's Greenhouse corporate accelerator program. The models are earlystage but have started generating product and business-model innovations, planting seeds of cultural change in the parent firms, and building external ecosystems with partners that range from startup companies to individual developers and makers.

Keywords: Ambidexterity, Dynamic capabilities, Open innovation, Operational models

\section{摘要}

本文探讨了大公司为成为更加创新平衡正在使用的新方法 ——更有能力为将来 在“利用”当前业务线时“探索”和创新。它通过与外部参与者的合作展示和比较了 三种不同的促进创新模式 —— 即GE设备公司新产品开发单位 FirstBuild,伊莱克斯 的开放式创新功能以及Lantmännen的Greenhouse企业加速器计划。这些模式处于 早期阶段,但已经开始生成产品和商业模式创新,在母公司中种植文化变革种子,并 与合作伙伴一起构建外部生态系统，从高技术初创公司到个体开发者和制造商。

关键词: 创新平衡, 动态能力, 开放式创新, 运营模式
\end{abstract}

\section{Résumé}

Cette étude examine de nouvelles approches utilisées par les très grandes entreprises pour devenir plus ambidextres et capables d'explorer et d'innover pour l'avenir tandis qu'elles exploitent les opportunités d'affaires actuelles. Elle présente et compare trois différents modèles pour booster l'innovation par le partenariat avec les acteurs externes: I'unité FirstBuildde de GE Appliances pour le développement de nouveaux produits, la fonction d'innovation ouverte chez Electrolux, et le programme accélérateur d'entreprise Greenhouse de Lantmännen. Ces modèles en sont encore à l'étape primitive, cependant, ils ont commencé à générer des innovations en termes de produits et de modèles d'affaires, en semant les graines de changement culturel dans les entreprises mères, et en construisant des écosystèmes avec des partenaires allant des starts-up à des développeurs et créateurs individuels.

Mots-clés: ambidextrie, capacité dynamique, innovation ouverte, modèles opérationnels 


\title{
Resumo
}

Este artigo examina novas abordagens que as grandes empresas estão usando para se tornarem mais ambidestras - mais capazes de "explorar" e inovar para o futuro enquanto "exploram" as linhas de negócios atuais. Apresenta e compara três modelos diferentes para impulsionar a inovação por meio da parceria com agentes externos: a unidade FirstBuild da GE Appliances para desenvolvimento de novos produtos, a função Open Innovation na Electrolux e o programa acelerador corporativo Greenhouse da Lantmännen. Os modelos estão em estágio inicial, mas começaram a gerar inovações de produtos e modelos de negócios, plantando sementes de mudança cultural nas empresas-mãe e construindo ecossistemas externos com parceiros que variam de empresas iniciantes a desenvolvedores e fabricantes individuais.

Palavras-chave: Ambidestria, Capacidades Dinâmicas, Inovação Aberta, Modelos Operacionais

\begin{abstract}
Аннотация
В настоящей статье рассматриваются новые подходы, которые крупные компании используют для обеспечения разностороннего развития - стимулирование открытости к новшествам и инновациями для внедрения "завтра", реализуемых в рамках "сегодняшней" бизнес-стратегии. Авторы выделили и сравнили три различные модели поддержки инноваций за счет установления партнерских отношений с внешними акторами: подразделение FirstBuild альянса GE для разработки новых продуктов, функции открытых инноваций Electrolux и корпоративная акселлерационная программа Lantmännen's Greenhouse. Представленные модели находятся на ранних этапах разработки, однако уже приносят результаты в виде новых продуктов и инноваций, давая начало культурных переменам в родительских компаниях и формируя внешнюю экосистему с различными партнерами (стартапы, индивидуальные предприниматели, производственные предприятия).
\end{abstract}

Ключевые слова: Разностороннее развитие, Динамические возможности, Открытые инновации, Операционные модели

\section{Resumen}

Examinamos nuevos modelos que las grandes empresas están utilizando para desarrollar la capacidad dual de "explorar" oportunidades de negocios y a la vez "explotar" las líneas de negocios actuales. Presentaos y comparamos tres modelos diferentes: la unidad para el desarrollo de nuevos electrodomésticos FirstBuild de General Electric, la directiva de innovación abierta de Electrolux, y el programa de acelerador corporativo Greenhouse de Lantmännen. Estos modelos están recién emergiendo pero han comenzado a generar innovaciones de productos y modelos de negocios, plantando semillas de cambio cultural en las empresas matrices y creando ecosistemas externos con socios que incluyen tanto empresas start-up como desarrolladores y fabricantes individuales.

Palabras clave: capacidades dinámicas, innovación abierta, modelos operativos 


\section{Multilingual abstract}

Please see Additional file 1 for translation of the abstract into Arabic.

\section{Introduction}

Large companies tend to become less innovative over time, as procedures and policies meant to strengthen existing lines of business seem to stifle exploration of the new. In times of discontinuous change, many previously successful firms have difficulties innovating and even surviving (March 1991). Dorothy Leonard's explanation is that when the environment changes-due, for example, to new technologies, consumer behavior, new regulations, or business models-the firm's core capabilities become core rigidities (Leonard-Barton 1992). Schumpeter (1942) saw old structures and businesses being replaced by new ones in perennial waves of "creative destruction" that lead to overall economic growth. For an individual firm, the challenge is to avoid destruction by remaining creative, and this paper will investigate some new ways of doing so.

In general, competitive advantage stems from creating value for customers in a better way than competitors do. Process management, standard operating procedures, and quality/lean approaches have been shown to be important for achieving this in mature high-volume markets (Womack and Jones 2003). But, in order to move beyond improvement of existing products and services, a company must pursue different strategies to cope with both the present business and innovation (Tushman and O'Reilly III 1997). As March put it: "The basic problem confronting an organization is to engage in sufficient exploitation to ensure its current viability and, at the same time, devote enough energy to exploration to ensure its future viability." (March 1991 p 105). The ability to "exploit" and "explore" simultaneously has been called ambidexterity (Tushman and O'Reilly III 1997). Questions of how best to achieve it have been on the agendas of practitioners and researchers for many years, yet the subject remains open to inquiry and practical experimentation.

The purpose of this paper is to describe and compare three operational models-each one in use at a different large firm-which have the following in common. There are attempts to solve the ambidexterity challenge and boost innovation by expanding the locus of innovation from the firms' traditional processes, such as internal R\&D, to include a specific section of the external community: small technology companies. In their smallest forms, these companies might consist of just one or a few people; the key point is that they are external to the large firm.

Shifting the locus of innovation in this way follows an open-innovation logic, which for the present paper is defined according to Chesbrough (2003): "Open Innovation is a paradigm that assumes that firms can and should use external ideas as well as internal ideas, and internal and external paths to market, as the firms look to advance their technology." Working with small, external tech companies is only one of many strategic avenues that a large firm can pursue for spurring innovation. In this paper, our focus is on this specific form of collaboration, not collaboration with universities, peer corporations, or other strategies for innovation. ${ }^{1}$

The sections below start with an overview of our theoretical frameworks: "ambidexterity" and "dynamic capabilities." Next come our research methodology, and a summary of findings from the three empirical case studies. The following discussion 
compares the cases to each other and to theory. The conclusions include avenues for further research.

\section{Theoretical frameworks: ambidexterity and dynamic capabilities}

Companies constantly face the challenge of satisfying today's customers while working on products, services or business models for tomorrow-ones that could even be a direct threat to today's. Tushman and O'Reilly (1997 p 14) described ambidextrous organizations as ones that "celebrate stability and incremental change as well as experimentation and discontinuous change simultaneously."

According to Teece et al. (1997), the winners in the global market have been firms that can demonstrate timely responsiveness and rapid and flexible product innovation, coupled with the management capability to effectively coordinate and redeploy internal and external competences. They refer to this source of competitive advantage as $d y$ namic capabilities. The term "dynamic" refers to the shifting character of the environment. The term "capabilities" emphasizes the key role of strategic management in adapting, integrating, and re-configuring internal and external skills and resources accordingly. Teece (2014) disaggregates dynamic capabilities into three core activities: (1) identification and assessment of technological opportunities in relation to customer needs ("sensing"); (2) mobilization of resources to address needs and opportunities, and to capture value from doing so ("seizing"); and (3) continued renewal ("transforming").

However, in parallel with these activities, the company also must manage the present business well, not least to obtain the financial resources for transformation. Here, Teece comments on the need for both dynamic capabilities, which are about "doing the right things," and ordinary capabilities which are about "doing things right." Therefore, as Birkinshaw et al. (2016) have noted, the ambidexterity perspective is a useful and even necessary complement to the dynamic capabilities perspective. Present theories on ambidexterity recognize different types.

\section{Types of ambidexterity and the shift to ecosystems}

O'Reilly III and Tushman (2013) identified three types of ambidexterity: sequential, simultaneous, and contextual. Companies practice the first when they modify their structures sequentially over time in response to changing needs for exploration or exploitation. But sequential ambidexterity might be ineffective in times of rapid change, so Tushman and O'Reilly III (1997) pointed to a need for simultaneous ambidexterity, with structurally separate sub-units for exploration and exploitation, and an involved top management able to dynamically balance the two. Both sequential and simultaneous ambidexterity focus on structural and corporate-governance means to solve the exploration/exploitation dilemma.

The third type, contextual ambidexterity, was identified by Gibson and Birkinshaw (2004), who defined it as the behavioral capacity to simultaneously demonstrate alignment and adaptability across an entire business unit. Contextual ambidexterity differs in its emphasis on individuals within a unit, rather than the management of multiple units, to make adjustments between exploration and exploitation. Birkinshaw et al. (2016) point out that rather than suggesting that one approach is inherently more effective than others, the choice of ambidexterity approach is influenced by both the 
environmental context and the organizational heritage of the firm, and the challenge is to develop a complementary set of capabilities. ${ }^{2}$

The Internet and cheap information processing have accelerated rates of change and product life cycles in many industries, driving companies to increase their focus on ambidexterity. IT and the Internet also have enabled greater collaboration with partners outside the firm, which has led to testing new collaborative approaches to innovation.

In accordance with Benner and Tushman (2015), we see two major challenges that firms must now face. One is to reconsider "traditional" views of innovation, and the other is addressing where innovation should be located-inside or outside company borders. Benner and Tushman (2015 pp 501-502) argued that because of dramatic reductions of communication and IT costs and the increasing modularization of products and services, both the fundamental mechanisms and the locus of innovation have shifted over the past decade, with the locus shifting from the firm to the community, where it follows an open-innovation logic (Chesbrough 2003).

Benner and Tushman (2015 p 502) called for scrutiny of established research knowledge of innovation and claimed a need for renewed empirical studies, writing as follows:

Many of our core organizing assumptions and associated research and theory may be outdated ... If the nature of innovation has shifted, then our research and theory on innovation must shift back to more inductive, or problem centered work.

This view is in line with previous observations on the subject (e.g. Teece 2014). O'Reilly III and Tushman (2013) noted that a promising domain for ambidexterity research is to move from the firm to its ecosystem as a unit of analysis, as innovation will increasingly occur across the larger community (Von Hippel 2005). Lakhani et al. (2012) noted that research is needed on the capabilities of firms in leading across boundaries, as well as on identity issues that span firm-community borders. When large firms rely increasingly on external technology and innovation, they must develop the ability to manage resources that they do not fully control. There is a need for understanding how to cultivate ecosystems (Steiber and Alänge 2013b; Furr et al. 2016) that can contribute to innovation but also require sharing wealth with others, on the assumption that the whole pie will grow.

\section{Small tech firms as a way of solving the ambidexterity challenge for large firms}

The strength of small technology startups is their ability to develop new ideas rapidly and test them with early-adopting customers, while a main weakness is limited ability to scale up for high-volume operations. Large firms typically show the opposite areas of strength and weakness. That has led some authors to suggest different ways of cooperation in which the firms play interactive and complementary roles (Rothwell and Dodgson 1991; Prashantham and Birkinshaw 2008).

However, Rothwell and Zegveld (1982 p 111) warned: "Because of the very different behavioral characteristics of large and small firms, such a relationship can be fraught with problems." Years later, Chesbrough (2002) noted that large companies had seen the value of investing in external startups; the trouble was that "More often than not, though, they just can't seem to get it right." And interviewees in Chesbrough's (2012) 
study of GE commented that it is inherently hard for very large companies to work with startups.

Some large firms have built successful strategies for combining their market strength with the nimbleness and creativity of external small firms, but they are not numerous. ${ }^{3}$ The following sections present some ways that large corporations have interacted with small firms in innovation processes that can work both from the "outside-in" and "inside-out" (Weiblen and Chesbrough 2015). ${ }^{4}$

\section{Previous research: approaches for large-small firm collaboration}

Chesbrough developed the open innovation concept from observations of inbound and outbound streams of technology at large firms (Chesbrough 2003). But while the concept is relatively recent, innovation activities that reach across company borders are not. In order to manage these activities, companies have created units that serve a boundary-spanning role (Thompson 1967), acting both as filters and facilitators (Aldrich and Herker 1977).

One such boundary-spanner is an internal open innovation function (Chesbrough 2003). This relatively new function usually does not, in itself, make investments in startups and other external partners. Rather it interacts with them to mediate access to ideas, innovations and competencies (Steiber and Alänge 2013b). The function (or parts of it) can be performed by various internal units such as technology offices, IP offices, and industry solution labs (Gassmann and Enkel 2004). Chesbrough emphasized that large firms need to balance the inbound and outbound flows of innovation, leading some units to assume broader responsibilities. For example, while IP offices had limited roles in large firms that mainly kept their patents for defensive reasons, they can play an extended role when licensing becomes a significant source of revenue.

Other examples of boundary-spanning units include corporate incubation units, where internal ideas may lead to spinout companies, which put internal assets to use and can also potentially be re-acquired later for integration into the firm. Further, corporate accelerator programs such as Fastworks in General Electric's Energy Storage division (Blank 2013) can work as a boundary-spanning unit.

Large firms have realized the need for rapid learning, and therefore, probe-and-learn processes have been introduced with success, primarily by computer and Internet companies (Lynn et al. 1996; Brown and Eisenhardt 1998; Steiber and Alänge 2013a, 2015). And more recently, the work of Steve Blank and Eric Ries has popularized their "lean startup" approach as a way to create internal probe-and-learn processes at traditional large companies such as GE (as in their Fastworks program just mentioned). The fundamental idea in lean startup is for the large company to quickly build a "minimum viable" product, test it with customers, and learn from this either how to proceed or to pivot and try a new approach (Blank 2005; Ries 2011). The corporate accelerators can be viewed as intensive programs in which cohorts of internal idea providers are trained to take their ideas further, either into solutions for current business areas or into new startups.

Another approach is corporate venture units investing in external startups of strategic interest, which (like corporate spinouts) may be acquired at some point. And acquisition in general is a common way of obtaining assets developed elsewhere-including technology, talent, competencies, and/or patent portfolios, in order to either develop or protect existing or future business areas (Steiber and Alänge 2013b). 
Finally, co-creation and co-location are new concepts of interest for this paper. Recently, there has been a growing interest in co-creation through crowdsourcing ideas from broader groups of developers, makers, and/or users. Terwiesch and Ulrich argued for the use of innovation tournaments to systematize the sensing, screening, and evaluation needed at the fuzzy front end, where new concepts are created and decided upon for development (Terwiesch and Ulrich 2009). Crowdsourcing of ideas is increasingly practiced, either within organizations or in designated communities, or in forms that are open to all. There are two basic approaches to crowdsourcing. A clearly defined problem can be presented for solution, or general challenge areas for innovation can be presented to invite broader idea generation. Some large firms have been stunned by the number of participants and have been slow in responding to them, while others have prepared by building nimble systems to review ideas and respond promptly with decisions-one example being GE's Ecomagination initiative (Chesbrough 2012). Sometimes co-creation involves hackathons, where idea providers also can go directly into a lab, to develop a first prototype within a very short time such as $48 \mathrm{~h}$. This way of democratizing innovation is related to the ideas of the Maker Movement (Hatch 2013). Through the Internet, the Maker Movement has expanded to global reach, and companies anywhere can even use third-party organizations that specialize in facilitating maker events and provide physical makerspaces for prototype work.

The makerspace idea has parallels in the corporate world, as some large firms have created labs or workspaces for small firms in their vicinity. The idea in many of these cases is to co-locate, so the small firms can benefit from access to the larger firms' competencies while the larger firms develop relationships that could provide useful innovation inputs (Remneland Wikhamn and Styhre 2017). Co-location has also been used with software developers, to stimulate them to write applications based on the large firm's software. This can expand the market reach of the software while helping the large firm develop its ecosystem (Gawer and Cusumanu 2014). Finally, some corporate "makerspaces" are designed primarily for internal people to develop and prototype their ideas; this use can be viewed as a form of an early-stage corporate incubator (as mentioned above).

\section{The integration of new ideas}

People have long known that it can be difficult to bring external ideas and innovations into an organization. The problem has been called the Not-Invented-Here (NIH) syndrome: literally, a resistance to anything invented elsewhere (Katz and Allen 1983). More recently, Lichtenthaler and Ernst (2006) argued for a need to recognize not only the NIH syndrome but also other "syndromes" that can affect the acquisition and exploitation of new knowledge. Hussinger and Wastyn (2015) point out that resistance to external knowledge is more likely if the company has been successful, as the employees then identify more strongly with their company. Resistance is also stronger if the knowledge comes from similar organizations such as competitors-and less so if it comes from suppliers, customers, or universities.

Companies have used a number of ways to integrate new ideas, whether they are imported from outside or must be moved across units internally: 
1) Movement of people between the unit creating the innovation and the business unit using it (Granstrand et al. 1988)

2) Building personal relationships between units-selecting people with social competence and existing networks (Hill and Birkinshaw 2014)

3) Early involvement of people from business units, to create a sense of ownership and to make the search for innovation more relevant for the business unit (Lichtenthaler and Ernst 2006)

4) Changing decision processes and incentive structures (Lichtenthaler and Ernst 2006)

5) Leadership support on different levels, to legitimize integration and put time and resources into it (Tushman and O'Reilly III 1997)

6) Senior managers must learn to overcome cognitive contradictions, build coordination mechanisms to generate an appropriate mix of exploration and exploitation, and attend to processes that can generate ambidextrous outcomes (Hill and Birkinshaw 2014)

7) Corporate ventures must develop an ambidextrous orientation themselves, building linkages to various external actors and integrating their activities with those of technical core units at their parent firm (Hill and Birkinshaw 2014 p 1905).

\section{Empirical research: methodology and introduction to the case companies}

As noted earlier, questions of how best to achieve ambidexterity at large firms remain open to inquiry and practical experimentation (Tushman and O'Reilly III 1997). This paper contributes to extended knowledge of ambidexterity by presenting three operational case studies from large firms.

Our research started in 2014 with an initial search for models for accelerating innovation via interaction between large and small firms. Through interviews with 23 large companies across Europe and the USA, we identified models reflecting 10 different approaches. To be able to provide a more in-depth description and empirical data of approaches that have been working successfully, we selected for this paper case studies reflecting three of the 10 approaches that were identified. ${ }^{5}$ These three cases were, in turn, selected on three primary criteria: They all demonstrate novel ways of working to solve the ambidexterity challenge; they have shown some visible positive results in the form of increased corporate innovation; and they represent different organizational solutions, which allows for analyzing similarities and differences.

After selecting the three case studies for the paper, we then returned to each company for further research. This consisted primarily of in-depth interviews with key persons, along with gathering additional information from secondary sources on the web and in print.

Our choices for this paper are as follows: GE Appliances' FirstBuild unit, Elextrolux and its Open Innovation approach, and Lantmännen and its "Greenhouse". We chose FirstBuild as a model to study interaction with small companies through a co-creation approach. GE Appliances utilizes FirstBuild as a new way to emulate a startup company using an open-innovation platform. The FirstBuild unit also functions as a boundary-spanner between the parent organization ${ }^{6}$ and external communities of developers and makers. 
Electrolux is another large firm ${ }^{7}$ with numerous brands produced by factories and business units that use different work approaches. The operational model studied here is the internal Open Innovation unit, which serves as a search and boundary-spanning hub between internal business units and external technology companies.

Finally, Lantmännen, ${ }^{8}$ the third case company, has relatively independent business units with their own approaches to innovation challenges. The selected operational model is linked to the corporate R\&D unit. Branded internally as the Greenhouse, it can be viewed as an internal accelerator program and also functions as a boundary-spanner, connecting internal R\&D and external research partners with the corporate strategy department, business units, and external independent incubators.

The three cases were analyzed following an analysis scheme based on issues identified in literature, including the following issues: approach, initial purpose; ambidexterity strategy; innovation focus; probe-and-learn processes; co-creation; top management role; integration with business units; evaluation process; use of standardized approaches; and implementation strategy.

\section{Operational models for ambidexterity: three case studies}

Following are summary descriptions of the three operational models. Each describes why and how the model was developed, how it functions, and challenges identified and lessons learned thus far.

\section{GE appliances and FirstBuild}

General Electric created FirstBuild in 2014 as a wholly owned subsidiary of GE Appliances, but also as a separate and legally independent unit. This was done to allow for an open-innovation environment not restricted by the established culture or practices. With assets including a physical microfactory and a web platform linking it to networks of external innovators and makers, FirstBuild explores new product concepts in home appliances. It is similar to a startup in its nimbleness and ability to work in rapid probe-and-learn processes. FirstBuild can manufacture small initial batches of new products and sell them to early-adopter customers, while finding new ways to reach them and obtain rapid feedback.

The birth of FirstBuild was triggered by frustration inside GE, as the R\&D organization was developing product concepts that met identified customer needs but did not reach the market if they fell slightly outside existing lines of business. This led to an interest in how startups bring new products to market rapidly, and GE tested the Lean Startup methodology (Blank 2013). That experiment provided useful insights and results, but also revealed the challenges of instituting such a methodology inside a large company built around efficient processes for production and distribution in mature markets. The conclusion was that something additional was needed, a different operating model.

Inspiration came from meetings with firms in the Maker Movement including Local Motors, MakerBot, and TechShop. Local Motors develops complex products, namely open-source cars, which are prototyped in small open-access factories. By combining in-house expertise with an online platform to crowdsource vehicle design and engineering ideas, the company can develop and launch new vehicles quickly at a fraction of 
the usual cost. GE signed a contract with Local Motors aimed at re-creating its "co-creation" process in the FirstBuild facility. MakerBot is a 3-D-printer company with an online forum, the Thingiverse, where FirstBuild can post problems and projects that MakerBot users can work on. TechShop (now defunct) operated a chain of makerspaces across the USA, providing another community to address problems and projects from FirstBuild.

FirstBuild also uses hackathons to innovate. The unit engages with innovators from its geographic region of Louisville, Kentucky, while reaching out globally for ideas via the Internet, and incorporating input from customers who buy and try new products. Further, all participants can "watch via social media as ideas speed from mind to market." ${ }^{9}$

FirstBuild's customers are pioneers willing to buy an innovative product, well aware that they are testing something that might need further work. They can be said to reflect the first 14\% in Rogers' (1995) diffusion of innovations model, wherein the initial $5 \%$ of users (Innovators) contribute ideas and the next 9\% (Early Adopters) provide good feedback to the product developers. The assumption is that a highly successful FirstBuild product could then be transferred to a regular GE Appliances business unit for scale-up and sale to customers who might lie farther down the Rogers curve.

In such cases, FirstBuild can provide a lot of data on the new product, including data on the test market that validated it. This is much more than an internal R\&D unit can offer, which typically is only an engineering prototype, without any customer feedback or actual market profile.

An essential asset of FirstBuild is its microfactory, where products can be made with advanced techniques and rapid prototyping tools. As production runs are small, typically below 1000-1500 units, the financial risk is limited and development time can be considerably shorter than when a large firm rolls out a new product.

FirstBuild is extremely open and transparent. Anyone can submit ideas and even build prototypes in the FirstBuild workshop. A promising idea can become an official project, with engineers and designers from GE Appliances helping to develop a more advanced prototype that then goes into low volume production.

There are clear rules for compensating external people who contribute to ideas that reach the market. As of this writing, the external party gets a modest initial cash award plus a percentage of net sales revenue, in return for giving First Build a perpetual non-exclusive license.

FirstBuild was launched with the backing of General Electric's CEO, whose top-level support was viewed as necessary: we were told that "nothing would happen" otherwise. The FirstBuild unit can afford to test approaches that could threaten the survival of a stand-alone startup, and it can do so without jeopardizing the larger firm's brand reputation, as the products are branded differently.

Aspects of this operational model can be changed quickly and responsively, because FirstBuild has a high degree of autonomy and control-although transferring a product to GE Appliances, and scaling it up there, can involve many aspects outside FirstBuild's direct control. In order to be truly successful as an innovation unit of a big company, FirstBuild must be able to develop relationships and contribute to cultural and organizational changes within the parent company's business units, which is a major challenge. 


\section{Electrolux and Open Innovation}

Over a number of years, the Electrolux Group has progressively increased investment in R\&D. Due to its consumer-oriented product-development process, R\&D collaborates internally with Marketing and Design.

In 2011, Electrolux decided to establish an Open Innovation function. One reason was to move beyond the traditional networks of partners, such as customers and suppliers, by building new networks with inventors and startups, as well as with large corporations in other industries and with universities. ${ }^{10}$

A senior employee with a background in R\&D was selected to build up and lead the function as Open Innovation Director. She needed to recruit a team of people who had both technical and business competence, were excellent communicators, and understood methods and tools for making an open innovation model work. She found the team members primarily through her personal network rather than through more traditional recruiting channels.

The Open Innovation team was given direct access to top management, in order to avoid bottlenecks and to act as a boundary spanner between external partners and internal stakeholders such as R\&D, Marketing, and others. While an Open Innovation unit could be designed to focus both inside-out and outside-in, Electrolux wanted the new unit to focus primarily on the external landscape. The plan was that the company would focus internal resources on strategic areas that had already been identified as promising, and Open Innovation would complement these efforts by finding external resources that could help, while also exploring new potential strategic areas. In this way, the new unit would increase Electrolux's ability to sense and mobilize for growth. As the company learned about new opportunities within not-yet-identified areas, strategic priorities were continuously screened, adjusted, and even changed.

Electrolux has used a "probe-and-learn" approach to arrive at an optimal praxis for the firm. Within 4 years of starting the Open Innovation unit, the company had developed an "Open Innovation strategy" consisting of three main pillars: Challenges, Networks, and Mindset.

Challenges are of two types, targeted and inspirational. Targeted challenges are specific problems for which the company wants solutions from outside players. Challenges of this type can be addressed through intermediaries or brokers such as NineSigma, and the Open Innovation team has developed networks with such parties. (Another source of external solutions would be innovation contests, but the Open Innovation Director views contests more as a tool for branding than for solving targeted problems effectively.)

Inspirational challenges are less tightly defined. They are generally aligned with one or more of Electrolux's strategic focus areas for innovation, and according to the company, they demand other types of external networks. Therefore, the Open Innovation team has built relationships with new partners that are efficient in searching, screening, and bringing new innovations to the firm. These new partners are VCs, Banks, and Incubators. They are chosen based on the ecosystems they are part of, with the best candidates having ecosystems that Electrolux also wants to be part of. Partners such as major banks and VC firms may have their own Open Innovation teams, who then become primary contacts for the Electrolux team. 
The Open Innovation team at Electrolux also has developed a method for increasing the absorptive capacity of the firm. It is based on a quarterly process in which the OI team "brainwashes" internal stakeholders to bring out what they need, and then lets external partners do the same with the team members and their search strategy. The external partners can then identify startups that have innovations matching the needs of Electrolux.

The banks, VCs, and incubators have been found to have robust systems for identifying and screening new tech companies of interest. Electrolux has made global agreements with some banks and VCs, initially in Europe, then in Asia and North America. The firm also has learned that these external partners can provide support in tricky situations such as dealing with intellectual property rights, which can become an issue when using external innovations.

At the time of our research, Electrolux claimed that $50 \%$ of incoming ideas matched the company's strategy well and were both of an incremental and more disruptive character. Further, $30 \%$ of the ideas led to new product categories and $20 \%$ of the ideas required new business models. These last were the toughest to manage internally as they required a higher acceptance of risk.

Since the time of our research, Electrolux has expanded its open innovation efforts in a new way. In April 2018, the company announced the creation of an "Innovation Factory" where external partners can co-locate and co-create (Electrolux 2018). At this writing, the first waves of project proposals were being evaluated for inclusion in the Factory, and it is far too early to judge how the venture will work out.

\section{Lantmännen and the Greenhouse}

The agricultural cooperative Lantmännen claims to be "Northern Europe's leader in agriculture, machinery, bioenergy and food products." Its new operational model for ambidexterity, the Greenhouse, is best understood by tracing the steps that led up to it.

Recognizing a need for long-term focus, Lantmännen had created a central R\&D unit, with the idea that its business units were to think and plan 36 months in advance while $R \& D$ took a somewhat longer view. Currently, the central R\&D unit works in three primary research areas that are directly linked to existing divisions and long-term business strategy.

One task of the R\&D unit is to collaborate with external researchers. A key resource for this has been the cooperative's research fund, which for over 25 years has financed work at selected universities and institutes or by single inventors through an open-call process. Projects tend to lean toward applied research and are chosen by three groups who meet quarterly to evaluate proposals in their areas. To assure strategic alignment, each group includes three representatives from the business units, three from the owners of the cooperative, and three from academia. ${ }^{11}$

In recent years, Lantmännen decided that this form of external collaboration was not enough. The $R \& D$ unit wanted to become more active in building an ecosystem, so it began to work with industry organizations and make small investments in startups. Here again, alignment with the business units was done through a reference group that included BU representatives.

In 2013, the R\&D Director decided to add two people with profiles different from those of typical R\&D staff. These people had a mix of both technical and business 
understanding, together with an entrepreneurial skill set. The main objective for the new team members was to spur the commercialization of important research results, either in existing business units or by starting a new unit or company. Another goal was to establish a more structured approach for moving ideas to market. Experiments with possible solutions led, eventually, to the Greenhouse. It is not an organizational unit of Lantmännen, but rather an internal accelerator program for the rapid development of promising ideas.

The Greenhouse process lasts 7 weeks, during which ideas are made into workable concepts, complete with business models. Concepts are presented to an internal "Dragon's Den" consisting of the heads of Strategy, M\&A, and R\&D along with representatives from certain business units. The 7-week program is facilitated by an external incubator that contributes with processes, tools, and inspirational lectures. Ideas can come from anywhere and anyone. Internal "idea carriers" are supported with some financing and receive help in discussions with their managers. Normally, there are project teams of two or three people working on each business idea, with several projects running in parallel. Clear selection criteria are then used in evaluating them. The Dragon's Den could decide that a particular business unit is to invest in a concept, or that a project will continue on a stand-alone basis, either under the care of central $R \& D$ or in an external incubator.

The Greenhouse has four purposes: (1) to collect innovative ideas internally and externally, through established networks; (2) to build employees' knowledge of business development generally, and specifically their innovation capabilities; (3) to create an innovation culture in the company; and (4) to earn more revenue. The Greenhouse program reports directly to the head of R\&D and is kept separately from Lantmännen's normal business, in keeping with the belief that normal business tends to neglect or even kill "new babies."

There have been challenges in implementing the Greenhouse process. The main initial hurdles were attracting enough ideas and convincing idea carriers to spend time driving projects through the accelerator program. A forum for ideas was therefore created on the company's Intranet, and members of the central R\&D unit have tried to actively engage with the business units and listen to their actual needs. During 2015, the $R \& D$ team conducted several internal road shows and campaigns to create awareness of, and interest in, the Greenhouse. As part of this effort, the R\&D team chose to emphasize the Greenhouse's educational component, and thus, it became identified mainly as a practical educational program for anyone with an innovative business idea.

By November 2015, the inflow of ideas had increased but the central R\&D team sought to have "idea flow responsible" individuals in each business unit. The central team also believes that people who have been through a Greenhouse project will positively affect their colleagues, leading more of them to conduct projects in the future. Corporate communication has played a major role in the entire process of change, as it has been crucial internally to convey the importance and business impact of innovations.

Nonetheless, integrating the Greenhouse concept across Lantmännen remains a challenge, as a not-invented-here culture tends to prevail within business units. Changing such a condition typically requires an ongoing cultural transformation. Key elements to drive a cultural shift at Lantmännen have included showing success cases, having an 
alert HR department that brings in the right new people, and maintaining good communication between the business units and the board.

The Greenhouse process is well supported by the executive management group. Despite the investment required, they see the Greenhouse as a mechanism that decreases the risk of missing important innovations needed for future growth. The executive group also believes that the Greenhouse enhances future-oriented thinking within the BUs by providing a more holistic firm-wide system for finding, screening, and developing new opportunities.

\section{Discussion}

Previous research has pointed to a need for more examples of operational models for ambidexterity, with the locus of innovation both internal and external to the firm (O'Reilly III and Tushman 2013). We have presented three such models that involve various forms of interaction with external small firms. In the sections below, the three cases will be analyzed on the basis of the following aspects: approach, initial purpose; ambidexterity strategy; innovation focus; probe-and-learn processes; co-creation; top management role; integration with business units; evaluation process; use of standardized approaches; and implementation strategy. For a summary comparison in brief, see Table 1.

\section{Approach}

Lantmännen's Greenhouse is a corporate accelerator established primarily to develop insiders' ideas. Potentially, their ideas could either be taken back to internal business units or be further developed for spin-outs with the cooperation with an external incubator, in which case external venture capital could also become involved.

The other two models are outside-in approaches; they primarily find and develop external ideas to benefit the large firm. FirstBuild is an independent (though wholly owned) product development and test market unit. The Electrolux Open Innovation function, on the other hand, serves as a mediator and linking organization that brings small creative firms in contact with Electrolux business units. The main purpose of both is to establish co-creation processes with external innovators, which in the case of both includes individuals as well as outside firms.

While the three operational models represent different ways of organizing to solve the ambidexterity dilemma, they have major similarities as well. We will now compare the models in terms of key issues mentioned above and shown in Table 1. With the table as a guide-and with reference to the case studies-we can discuss the models further while considering how they reflect current theories of ambidexterity. We will also highlight some practical examples of dynamic capabilities, a theory which earlier in this paper was presented as complementary to the theory of ambidexterity.

\section{Initial purpose}

Along with striving to increase the flow of innovations, an important purpose of all three models is to contribute to culture change at the parent firm-opening it to new approaches for accelerating innovation, in parallel with "exploiting" its present offerings. At FirstBuild, engineers from business units can participate in the development of 


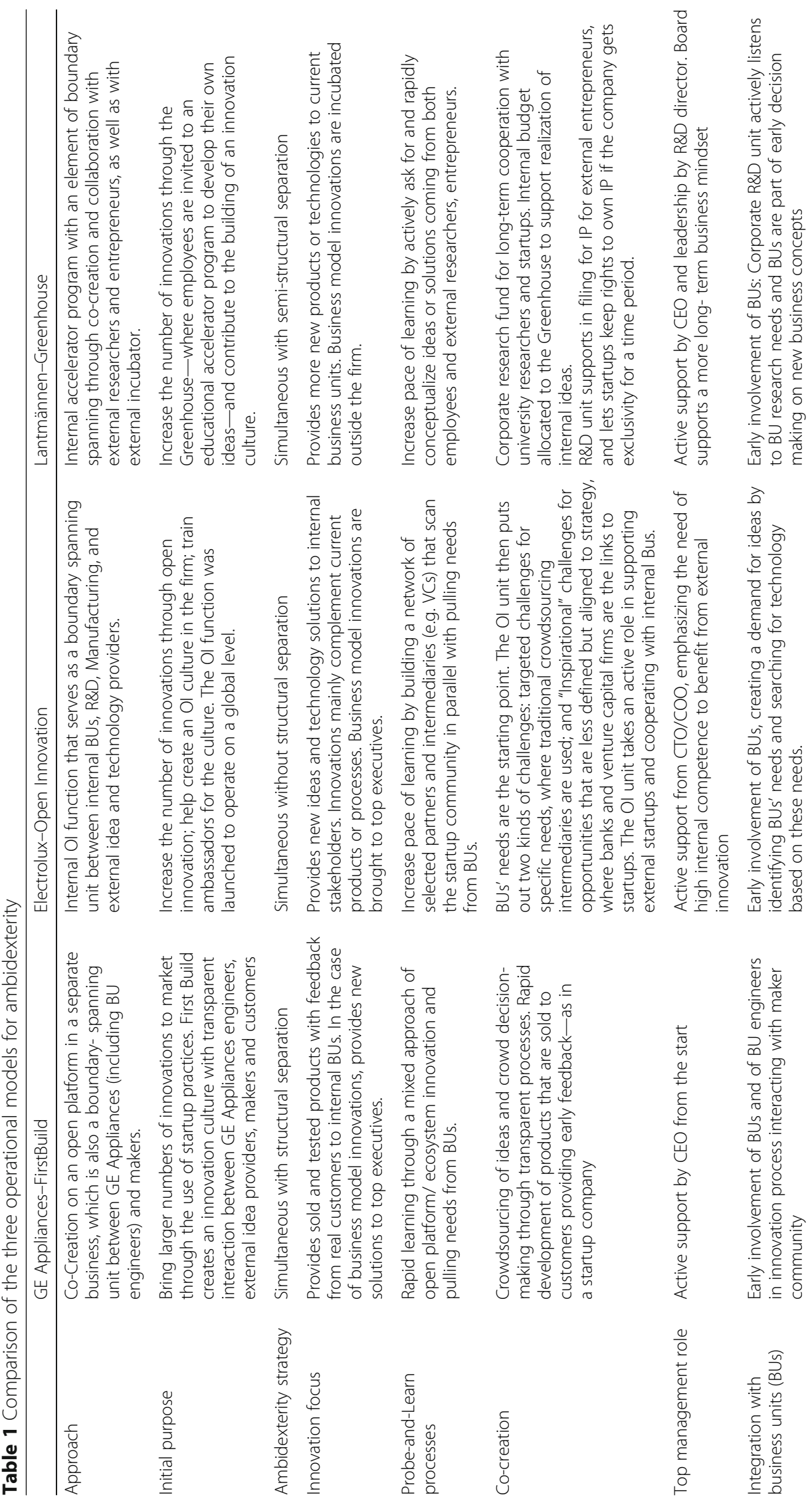




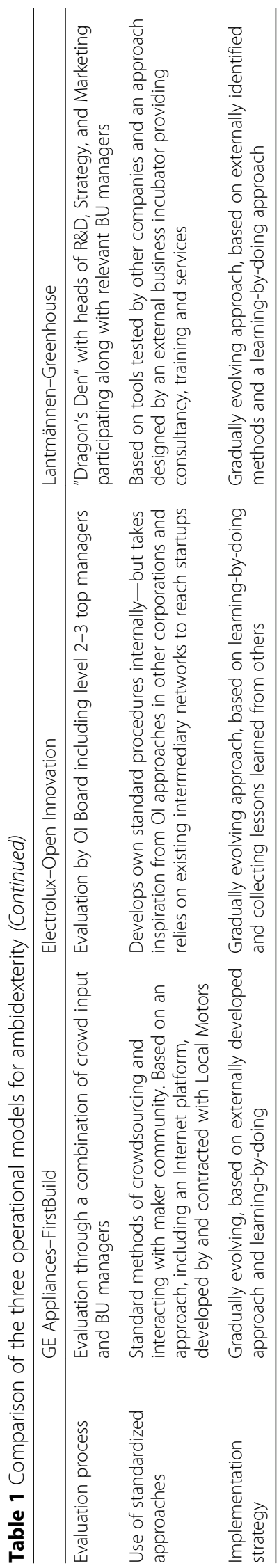


new products, which involves them in open-innovation and startup-style practices. The Open Innovation function at Electrolux is intended to increase the number of externally generated innovations used by business units, and these units are involved from the start. Electrolux also found a need to train people as internal ambassadors for an open innovation culture. Lantmännen has emphasized the educational aspect ${ }^{12}$ of its Greenhouse program, which trains people in accelerated-innovation practices. The people are then expected to propagate the new approaches within the existing business units, and Lantmännen reinforces this with internal communications promoting both the Greenhouse program and broader cultural change.

And one further note is in order here: Although all three case companies have aimed for broad cultural change-which, in each case, has been a gradual work-in-progress - the companies have realized positive results in the form of innovations developed and implemented. As will be mentioned shortly, FirstBuild has had a major new product integrated into an existing product line, while the other two companies have had various innovations adopted by BUs (and even, at Lantmännen, launched as spinout ventures).

\section{Ambidexterity strategy}

In the literature on ambidexterity, we find that the traditional "sequential" approach of adjusting between exploration and exploitation has been outdated by rapid change (Tushman and O'Reilly III 1997). Firms must find ways to simultaneously explore and exploit. All three models are aimed at this form of ambidexterity but differ in organizational approach and strategy.

FirstBuild operates separately and autonomously to a high degree. At Electrolux, innovation is internally based but the Open Innovation function facilitates access to external contributions. Lantmännen's Greenhouse is an internal program with semi-structural separation from the company's normal operations, and it is run in concert with an external incubator.

Although Tushman and O'Reilly emphasized a need for structural separation, Benner and Tushman (2015) opened up to a more complex reality in which the locus of innovation, inside or outside the parent organization, becomes an important factor to consider. In all three cases we studied, the locus of innovation can be found at least partly outside the organization, but only one model (FirstBuild) has the innovation unit firmly separated in structure.

\section{Innovation focus}

The three operational models all spur innovations and utilize external input, but the innovation focus is different among them. FirstBuild develops and market-tests new home appliance products, using open innovation and startup practices that are not common in large firms. If some of the products are to be made and sold in high volumes later, they will have to fit into the current processes of the parent organization.

The Electrolux OI function is primarily a boundary-spanner between external innovation suppliers and internal stakeholders, and it sees its role as supporting both parties. The OI function broadens its search by tapping networks of intermediaries such as banks and VCs, which is a new twist procedurally. However, the focus is on 
finding innovations quite close to current business lines, although the OI function is also open to business model innovations.

At Lantmännen, the focus is both on technological and business model innovations from the start. While existing business units can sponsor and bring new product concepts into the Greenhouse development process, the company partners with an external incubator to handle business model innovations.

\section{Probe-and-learn processes}

All three models enable rapid learning of new business opportunities, and they share the ambition of having their firms seize these opportunities. The way the different firms choose to learn is, however, quite different. At FirstBuild, rapid learning is enabled by an open platform for external product ideas that can be tested with probe-and-learn processes providing real customer data (Ries 2011). In the Open Innovation function, learning is achieved by building a network of partners/intermediaries who have access to expertise and ideas that Electolux could use. Lantmännen's Greenhouse achieves rapid learning by offering a new way to collect, develop, and evaluate employees' ideas, while also engaging with external innovators and entrepreneurs. Co-locating the internal and external people could also provide learning advantages (Remneland Wikhamn and Styhre 2017).

\section{Co-creation}

Both FirstBuild and the Greenhouse are arenas for co-creation. The Open Innovation function at Electrolux is not, in itself, such an arena, but by serving as a search-and-bridging mechanism, it makes connections that can lead to innovation across boundaries (Gassmann and Enkel 2004). And looking ahead, the company's new Innovation Factory is intended as a physical co-creation platform.

FirstBuild, meanwhile, was explicitly set up for co-creation from the start. Crowdsourcing, user input, and participation by makers and others are core features of the open-platform process (Chesbrough 2012; Hatch 2013; Gawer and Cusumanu 2014). The Greenhouse is an internal accelerator program that act as an innovation arena and boundary spanner between internal business units, $R \& D$, and external actors.

\section{Top management's role}

Top management has played a supportive role in all three cases. In each, the head of the new operational model had direct contact with the firm's CEO, and in two cases (Electrolux and Lantmännen) a direct reporting line to the top level. The importance of top-management support has been underscored by almost all change theories and practitioners (e.g., Kotter 1996) and has also been emphasized by scholars studying transformations from dynamic capabilities and ambidexterity perspectives (Tushman and O'Reilly III 1997; Birkinshaw et al. 2016). Such top-level management support is clearly visible here. Additionally, the Greenhouse has board-level support, which provides long-term development stability, a factor not so commonly identified in other studies (Alänge and Steiber 2009). 
Integration with business units

As noted earlier, the integration of externally developed ideas has been found difficult in many corporations (Katz and Allen 1983; Hussinger and Wastyn 2015). The three models in our case studies strive for early involvement of business units, to help pave the way toward integration of what is found or developed, and this can be viewed as building integrative capabilities.

In the Open Innovation function at Electrolux, internal business units along with $R \& D$, manufacturing and marketing participate from the start to create a "wish list" based on their needs. Starting from perceived needs of the business areas can help to obtain their buy-in, while focusing the search for external technologies/businesses to link up with (Lichtenthaler and Ernst 2006). At FirstBuild, engineers from business units take part in early idea development, which is one aspect of building ambidextrous orientation by keeping good contacts with regular business units within the parent corporation (Hill and Birkinshaw 2014). Lantmännen business units are asked to express their needs and invited to be part of decision making on early-stage product/business concepts in the Greenhouse. The importance of such involvement has been emphasized in general change-management literature as a major success factor (Nadler and Tushman 1997). It has also been identified as a higher-order dynamic capability if a firm reconfigures through resource linking (simultaneous ambidexterity/structural separation) or context shaping (contextual ambidexterity/ behavioral integration), activities that are usually directed from the top executive level (Birkinshaw et al. 2016). In all three cases, integration mechanisms are built into the operational models and upheld by leaders on that level, with support from the top level (Tushman and O'Reilly III 1997). However, the specific design depends on the ambidexterity approach chosen and on the cultural heritage and environmental context of the firm (Birkinshaw et al. 2016).

\section{Evaluation process}

In all three models, the evaluation of concepts is done by high-level managers with (immediate) decision-making capacity. This is also practiced by other companies that use hackathons for product development, such as Facebook, where the leadership group including founder Mark Zuckerberg can make rapid decisions on continued development of prototypes (Steiber and Alänge 2016). A lack of decision-making ability, on the other hand, has been identified as a major hindrance for absorption of new ideas and a major cause of time delays, whether the ideas come from inside or outside the firm (Komssi et al. 2015).

The difference between our three models is in how evaluation is conducted. FirstBuild uses crowd input both for ideas and for initial decision-making on concepts to develop, and then the decision-making for GE Appliances' business units is based on a verified product concept with customer data. The Greenhouse uses a decision forum consisting of a few core executives, plus people with the knowledge and mandate to decide on the project being reviewed. In the Open innovation function, this kind of forum, with the CEO participating, has been used in cases where the OI function had identified and recommended business model innovations. If the innovation is more of a complement to current business, the decision is made by the relevant business unit or functional head, e.g. the head of R\&D. 


\section{Use of standardized approaches}

The FirstBuild approach is itself to some degree standardized (Steiber and Alänge 2015), as it is built on Local Motors' Internet platform and its tested approach. The Greenhouse approach was built with external assistance from a business incubator that used proven methods previously tested on many early-stage startups. Electrolux's Open Innovation strategy and methods were inspired by forerunners in the open innovation area (e.g., Procter \& Gamble) and were also informed by companies in other industries that had developed OI approaches (e.g. Swarovski and Philips). The Electrolux approach also includes unique elements, such as the OI strategy with three pillars-Network, Challenges and Mindset. However, operational models for exploration (e.g., innovation management) are typically not as standardized as models focusing on exploitation, such as lean production (Steiber and Alänge 2015).

\section{Implementation strategy}

In the implementation of all three models, a search for existing methods and tools was conducted initially. However in all cases, there was also an emphasis on learning-by-doing (Steiber and Alänge 2015). It is hard to get everything right from the start, even when starting from a more standardized approach as FirstBuild did. Many areas still need testing and development, not least around the issue of integration with business units, which is an important measure of value from the parent firm's perspective. In our research on the models, we found that all units understood the importance of involving central decision makers in the process, although the specific ways of organizing the involvement have been developing gradually.

Up to the time of our research, somewhat different challenges had been identified with the three models. At FirstBuild, integrating newly developed products and technologies with the parent company largely remained an unresolved issue. However, more recently, there has been success in this area. For example, a major FirstBuild product-a home pizza oven, selling for over US\$9000-was added to the existing line of luxury "Monogram" items at GE Appliances (Kapoor et al. 2017). A big challenge with the Open Innovation function at Electrolux has been developing and integrating business model innovations; there is also a need for better metrics to evaluate more radical innovations. And the Greenhouse team recognized that internal entrepreneurs have challenges of their own. One is just finding the time to develop new things while doing their current jobs, which the Greenhouse team has addressed by measures such as negotiating with people's managers for innovation time.

The three approaches, at the time of the study, had already produced positive outcomes in terms of an increase in innovations. Further, they point to the possibility of organizing for ambidexterity in different ways, depending on the needs, history, and context of the firm. This suggests that the principle of equifinality applies: that there is no single path to ambidexterity (Alänge et al. 2016), and consequently, companies may rely on different specific dynamic capabilities (Birkinshaw et al. 2016). As seen from the discussion above, each of the three models for solving the ambidexterity challenge has, over time, developed its own forms of dynamic capabilities. The cases especially 
show various ways the operational models are constructed to improve the parent firms' abilities in "sensing" and "seizing"-not least through the use of boundary spanning practices, which are essential when the locus of innovation shifts to include external parties. Furthermore, as noted in the case descriptions, firms typically use a number of ways to move toward a goal, as the purposes and results of the various ways differ somewhat and often can be seen as complementing each other (Steiber and Alänge 2013b). Finally, it is worth noting that the three models have been primarily directed toward innovations that are complementary to existing businesses, not toward totally disruptive innovation.

\section{Conclusions}

All three models are making contributions to ambidexterity at their parent firms. The models are early-stage, and at the time of our research, none had yet produced high-impact innovations that are sold or used widely, but they have been generating innovations and putting them into the pipeline (plus, at FirstBuild, onto test markets) in growing numbers. They are building external networks of innovation partners and propagating new practices internally, thus enhancing their parent firms' ability to explore and exploit simultaneously. Thus, these models are all contributing to the parent firms' dynamic capabilities in terms of sensing, seizing, and transforming.

They are all designed to produce technology and product innovations that fit in with current businesses, although they allow business model innovations to different degrees. FirstBuild was set up to develop and test new product concepts with real customers in an unorthodox way, but the primary ambition is still to renew current businesses by providing these market-tested product innovations. Electrolux's Open Innovation approach is also more focused on enhancing current businesses, based on identified needs, while the Lantmännen setup allows for both complementary and radical innovation.

The models all enable co-creation with external players. The differences are in the degree of openness to outsiders, the degree of co-creation, and how involved the external players are in the early phases of the innovation process. FirstBuild allows high degrees of openness ${ }^{13}$ and co-creation, along with high involvement in idea generation and development. The Electrolux model is more limited and selective in its openness, looking for more developed innovations and having less active engagement of external players in the idea phase (although the "inspirational" searches allow greater engagement). Lantmännen's Greenhouse is somewhere between the two others.

As noted, integrating new concepts or solutions into current business units is a challenge for all. Electrolux addressed the issue, in part, by gathering internal stakeholders' needs quarterly. This approach however risks becoming more focused on innovations complementing and improving current businesses, rather than building new businesses. On the opposite side is FirstBuild, with an initial intention of including innovations that could change current businesses. In that case, integration of the new products with existing businesses could therefore be very challenging and will need strong support from top leadership. Lantmännen, meanwhile, has different strategies depending on the type of innovation. For innovations close to current businesses, the Greenhouse program demands a business unit sponsor. If the innovation is more "novel," potentially a 
new business in itself, it is incubated either within R\&D or at the external incubator that Lantmännen has partnered with.

Finally, the three models share a number of critical success factors such as an engaged top leadership, knowledge transfer from external role models who could provide proven concepts, evaluation processes performed by executives with direct decision power, and a probe-and-learn approach to implementation.

A number of managerial implications can be drawn from the models. One can start with similarities like the success factors just mentioned, and early involvement of business units to help with integration. However, the three cases also point to the possibility of organizing for ambidexterity in different ways. When the principle of equifinality applies and there is no single path to ambidexterity, companies may rely on different specific dynamic capabilities. Furthermore, as noted, firms typically use a number of ways to move toward various goals and purposes, which often can be seen as complementing each other.

\section{Future research}

The three models presented here provide some further understanding of tangible ways to organize the "exploration" function in large firms, and thereby increase their ambidexterity. However, many combinations of approaches are possible and need to be further tested in practice and researched, including new ways of co-creating without equity investment. Our own previous research has identified up to 10 different approaches that involve using large firm-small firm collaboration. We plan to publish a paper summarizing these, in the form of a strategic framework for managers, while continuing to publish on a more detailed level new operational models for ambidexterity, including other sections of the external community.

There is also a need for more research and new perspectives on the actual use of external innovation-including on integrative capability, which is crucial to ultimate success. The three models also provided insights into other unique or shared dynamic capabilities that need to be further scrutinized in order to develop a thorough contextual understanding of strengths and weaknesses of models for ambidexterity.

\section{Endnotes}

${ }^{1}$ The three large firms serving as our case companies do, in fact, collaborate with universities and other external parties (including government agencies) for research and innovation. Our paper does not address these activities for a simple reason: they are not distinguishing features of the operational models that we describe.

${ }^{2}$ Birkinshaw et al. (2016) presented success cases of all types of ambidexterity approaches: e.g. BMW using the sequential approach, Nestlé the simultaneous through structural separation, and GSK the contextual through behavioral integration.

${ }^{3}$ One example is Cisco Systems, pursuing spin-ins and incubation simultaneously. See Sidhu (2010).

${ }^{4}$ Taking another perspective, Prashantham and Birkinshaw (2008) suggested strategies for small firms to successfully engage with MNCs. Based on the concept of strategic asymmetry, they emphasized the importance of: ensuring flexibility, accepting uncertainty, undertaking constant review, and exploiting assymetric advantages. Usman and Vanhaverbeke (2017) provide another account of how startups can organize and 
manage open innovation activities with large corporations - emphasizing the role of startup managers and the advantage of them having prior experience of working in/ with a large company.

${ }^{5} \mathrm{An}$ article including all 10 is planned for the near future.

${ }^{6}$ GE Appliances, with about 12,000 employees and annual revenues (2017) of US\$6.9 billion, makes home appliances ranging from refrigerators and stoves to laundry washers and air conditioners. A longtime division of General Electric, GE Appliances was sold to the Haier Group in 2016: (https://www.cnet.com/news/its-official-ge-appliances-belongs-to-haier/ accessed July 19, 2018)

${ }^{7}$ Electrolux is a global home appliance manufacturer with brands and products including Electrolux vacuum cleaners and Grand Cuisine cooking systems, AEG and Zanussi appliances, and Frigidaire. In 2017, Electrolux had sales of SEK 122 billion and about 55,000+ employees: (http://www.electroluxgroup.com/en/company-overview-271/ accessed July 19,2018)

${ }^{8}$ Lantmännen is an agricultural-products cooperative owned by about 25,000 Swedish farmers. With about 10,000 employees and operations in over 20 countries, the cooperative makes grain-based food products, ethanol and related fuels. In 2017, Lantmännen had sales of SEK 39.7 billion: (https:/lantmannen.com/siteassets/documents/ 01-om-lantmannen/press-och-nyheter/publikationer/arsredovisningar/annual-report-with-sustainability-report-2017.pdf accessed July 19, 2018)

${ }^{9}$ From the FirstBuild website, accessed Oct. 27, 2016 at https://firstbuild.com/co-create/.

${ }^{10}$ In many cases, Electrolux's collaborations with a variety of external partners are supported, in part, by EU funding for innovation. We therefore find here a typical example of a Triple Helix approach. However, as mentioned earlier, this paper examines ambidexterity models that involve collaborating with external small companies; we will not go into aspects of university or government participation.

${ }^{11}$ With Lantmännen, as with Electrolux, we again find collaboration with external partners that include both universities and government. The latter has come into play in cases where Lantmännen co-funds innovation projects together with the Swedish innovation agency Vinnova. We therefore can call this another typical example of a Triple Helix approach.

${ }^{12}$ The educational component was emphasized in order to make the program even more attractive to employees. Not only could they have an impact on the firm, but they would also learn a new mindset and new ways of working that can be beneficial to them in their future careers.

${ }^{13}$ By "degree of openness" we mean a high degree of "reach" and a limited pre-selection of who can be involved in the co-creation process.

\section{Additional file}

Additional file 1: Translation of the abstract into Arabic. (PDF $58 \mathrm{~kb}$ )

\section{Abbreviations}

3-D: Three dimensional; BU: Business Unit; CEO: Chief Executive Officer; COO: Chief Operating Officer; CTO: Chief Technology Officer; GE: General Electric; IP: Intellectual Property; OI: Open Innovation; R\&D: Research and Development; US: United States of America; VC: Venture Capital 
Funding

Grant 2014-00939 from Swedish Government Agency Vinnova to conduct the research upon which this article is based.

\section{Authors' contributions}

The two authors' contributions are equal. Both authors read and approved the final manuscript.

\section{Competing interests}

The authors declare that they have no competing interests.

\section{Publisher's Note}

Springer Nature remains neutral with regard to jurisdictional claims in published maps and institutional affiliations.

\section{Author details}

'Department of Technology Management and Economics - STS, Chalmers University of Technology, SE-412 96 Gothenburg, Sweden. ${ }^{2}$ Menlo College, 1000 El Camino Real, CA 94027-4301 Atherton, California, USA.

Received: 21 January 2018 Accepted: 21 April 2018

Published online: 22 August 2018

\section{References}

Alänge S, Clancy G, Marmgren M (2016) Naturalizing sustainability in product development: a comparative analysis of IKEA and SCA. J Clean Prod 135:1009-1022

Alänge S, Steiber A (2009) The board's role in sustaining major organizational change. International Journal of Quality and Service Sciences 1(3):280-293

Aldrich H, Herker D (1977) Boundary spanning roles and organization structure. Acad Manag Rev 2(2):217-230

Benner MJ, Tushman ML (2015) Reflections on the 2013 decade award - 'exploitation, exploration, and process management: the productivity dilemma revisited' ten years later. Acad Manag Rev 40(4):497-514

Birkinshaw J, Zimmerman A, Raisch S (2016) How do firms adapt to discontinuous change? Bridging the dynamic capabilities and ambidexterity perspectives. Calif Manag Rev 58(4):36-58

Blank S (2013) Why the lean start-up changes everything. Harv Bus Rev 91(5):63-72

Blank SG (2005) The four steps to the epiphany: successful strategies for products that win, 3rd edn. Quad/Graphics, Sussex

Brown S, Eisenhardt KM (1998) Competing on the edge: strategy as structured chaos. Harvard Business School Press, Boston

Chesbrough H (2002) Making sense of corporate venture capital. Harv Bus Rev 80(3):90-99

Chesbrough H (2003) Open innovation: the new imperative for creating and profiting from technology. Harvard Business School Press, Boston, MA

Chesbrough H (2012) GE's ecomagination challenge: an experiment in open innovation. Calif Manag Rev 54(3):140-154

Electrolux (2018) Electrolux launches its first open innovation factory. Corporate press release, 10 April 2018. Also see the Electrolux Innovation Factory website at https://www.innovationfactory.digital/ (accessed 19 July 2018)

Furr N, O'Keeffe K, Dyer JH (2016) Managing multiparty innovation: how big companies are joining forces to seize opportunities at their intersections. Harvard Business Review:76-83

Gassmann O, Enkel E (2004) Towards a theory of open inenovation: three core process archetypes. R\&D Management Conference (RADMA), Lisbon

Gawer A, Cusumanu MA (2014) Industry platforms and ecosystem innovation. J Prod Innov Manag 31(3):417-433

Gibson CB, Birkinshaw J (2004) The antecedents, consequences, and mediating role of organizational ambidexterity. Acad Manag J 47(2):209-226

Granstrand O, Sjölander S, Alänge S (1988) Strategic technology management issues in Japanese manufacturing industry. CIM Working Paper WP-1988-06

Hatch M (2013) The maker movement manifesto: rules for innovation in the New World of crafters, hackers, and tinkerers. McGraw-Hill, New York

Hill SA, Birkinshaw J (2014) Ambidexterity and survival in corporate venture units. J Manag 40(7):1899-1931

Hussinger K, Wastyn A (2015) In search for the not-invented-here syndrome: the role of knowledge sources and firm success. R\&D Management (accessed on-line 10 march 2016)

Kapoor B, Nolan K, Venkatahrishnan N (2017) How GE appliances built an innovation lab to rapidly prototype products. Harvard Business Review Experimentation July 21:2017 https://hbr.org/2017/07/how-ge-built-an-innovation-lab-torapidly-prototype-appliances

Katz R, Allen TJ (1983) Investigating the Not Invented Here (NIH) svndrome: a look at the performance, tenure, and communication patterns of 50 R \& D Project Groups. R\&D Manag 12(1):7-19

Komssi M, Pichlis D, Raatikainen M, Linström K, Järvinen J (2015) What are hackathons for? IEEE Software 2015:60-67

Kotter JP (1996) Leading change. Harvard Business School Press, Boston

Lakhani KR, Lifshitz-Assaf H, Tushman ML (2012) Open innovation and organizational boundaries: the impact of task decomposition and knowledge distribution on the locus of innovation, Working Paper 12-057. Harvard Business School, Cambridge

Leonard-Barton D (1992) Core capabilities and core rigidities: a paradox in managing new product development. Strategic Management Journal 13(Issue S1):111-125

Lichtenthaler U, Ernst H (2006) Attitudes to externally Organising knowledge management tasks: a review, reconsideration and extension of the NIH syndrome. R\&D Manag 36(4):367-386 
Lynn G, Marone J, Paulson A (1996) Marketing and discontinuous innovation: the probe and learn process. Calif Manag $\operatorname{Rev} 38(3): 8-37$

March JG (1991) Exploration and exploitation in organizational learning. Organ Sci 2:71-87

Nadler DA, Tushman ML (1997) Implementing new designs: managing organizational change. In: Tushman ML,

Anderson P (eds) Managing strategic innovation and change: a collection of readings. Oxford University Press, New York, pp 595-606

O'Reilly CA III, Tushman ML (2013) Organizational ambidexterity: past, present, and future. The Academy of Management Perspectives 27(4):324-338

Prashantham S, Birkinshaw J (2008) Dancing with the gorillas: how small companies can partner effectively with MNCs. Calif Manag Rev 51(1):6-23

Remneland Wikhamn B, Styhre A (2017) Open innovation as a facilitator for corporate exploration. Int J Innov Manag 21(6):1-20

Ries E (2011) The lean startup: how constant innovation creates radically successful businesses. Portfolio Penguin, London

Rogers EM (1995) Diffusion of innovations, 4th edn. Free Press, New York

Rothwell R, Dodgson M (1991) External linkages and innovation in small and medium-sized enterprises. R\&D Manag 21(2):125-137

Rothwell R, Zegveld W (1982) Innovation and the small and medium sized firm. Frances Pinter, London

Schumpeter JA (1942) Socialism. Capitalism and Democracy, Harper \& Brothers, New York, NY

Sidhu I (2010) Doing both: how CISCO captures today's profit and drives tomorrow's growth. FT Press, Upper Saddle River, NJ

Steiber A, Alänge S (2013a) A corporate system for continuous innovation: the case of Google Inc. Eur J Innov Manag 16(2):243-264

Steiber A, Alänge S (2013b) The formation and growth of Google Inc:. a firm-level triple Helix perspective. Soc Sci Inf 52(4):575-604

Steiber A, Alänge S (2015) Organizational innovation: verifying a comprehensive model for catalyzing organizational development and change. Triple Helix 2(14):1-28

Steiber A, Alänge S (2016) The Silicon Valley Model: Management for Entrepreneurship. Springer, Cham

Teece DJ (2014) The foundations of Enterprise performance: dynamic and ordinary capabilities in an (economic) theory of firms. The Academy of Management Perspectives 28(4):328-352

Teece DJ, Pisano G, Shuen A (1997) Dynamic capabilities and strategic management. Strateg Manag J 18(7):509-553

Terwiesch C, Ulrich KT (2009) Innovation tournaments: creating and selecting exceptional opportunities. Harvard Business Press, Boston

Thompson JD (1967) Organizations in action: social science bases of administrative theory. McGraw-Hill, New York

Tushman ML, O'Reilly CA III (1997) Winning through innovation: a practical guide to leading organizational change and renewal. Harvard Business School Press, Boston

Usman M, Vanhaverbeke W (2017) How start-ups successfully organize and manage open innovation with large companies. Eur J Innov Manag 20(1):171-186

von Hippel E (2005) Democratizing Innovation. MIT Press, Cambridge

Weiblen T, Chesbrough HW (2015) Engaging with startups to enhance corporate innovation. Calif Manag Rev 57(2):66-90

Womack JP, Jones DT (2003) Lean thinking: banning waste and create wealth in your corporation. Free Press, New York

\section{Submit your manuscript to a SpringerOpen ${ }^{\circ}$ journal and benefit from:}

- Convenient online submission

- Rigorous peer review

- Open access: articles freely available online

- High visibility within the field

- Retaining the copyright to your article

Submit your next manuscript at $\boldsymbol{\nabla}$ springeropen.com 